\title{
INGESTIA CONCOMITENTĂ DE ETILENGLICOL ŞI ETANOL: O CAPCANĂ DE DIAGNOSTIC?
}

\author{
Otilia-Elena Frăsinariu1, ${ }^{1,2}$, Aniela Rugină ${ }^{1,2}$, Cristina Jităreanu², Radu Russu ${ }^{2}$, \\ Nicolai Nistor ${ }^{1,2}$, Violeta Ştreangă ${ }^{1,2}$ \\ 'Disciplina de Pediatrie, Universitatea de Medicină şi Farmacie „, Gr. T. Popa “, Iaşsi \\ ${ }^{2}$ Spitalul Clinic de Urgență pentru Copii ,,Sf. Maria“", Iaşi
}

\begin{abstract}
REZUMAT
Etilenglicolul este unul dintre cei mai toxici alcooli, fiind consumat accidental sau voluntar, ca substituent al etanolului sau în scop suicid. Ingestia de etilenglicol determină, prin metaboliții săi toxici, acidoză metabolică severă, cu creşterea hiatusului anionic şi osmotic, conducând la un tablou clinic ce asociază deprimarea sistemului nervos central, afectare cardiovasculară şi insuficiență renală. Prezentăm cazul unui pacient în vârstă de 16 ani internat pentru semne clinice şi biologice de intoxicație cu etilenglicol apărute după ingestia simultană de antigel şi alcool. Pacientul a prezentat acidoză metabolică doar la debut, rapid corectată de o doză de bicarbonat de sodiu; investigațiile ulterioare nu au relevat acidoză, chiar dacă în evoluție a apărut insuficiența renală acută ce a necesitat hemodializă. Datorită absenței anamnezei pozitive şi a acidozei metabolice persistente, diagnosticul de intoxicație cu etilenglicol a fost întârziat până la confirmarea prin testul toxicologic seric. Concluzii: ingestia concomitentă de etanol poate masca simptomele intoxicației cu etilenglicol; absența acidozei metabolice persistente nu exclude diagnosticul.
\end{abstract}

Cuvinte cheie: etilenglicol, acidoză metabolică, insuficiență renală acută, hemodializă, intoxicație

\section{INTRODUCERE}

Etilenglicolul (EG) este un alcool toxic, incolor, inodor, ce se găseşte în antigel, în lichidul de frână, ca stabilizator în agenții spumanți, solvenți. Datorită gustului dulce, copiii sunt predispuşi să-l consume în cantități mari, rezultând intoxicații accidentale (1).

Etilenglicolul este metabolizat în cea mai mare parte de către alcooldehidrogenaza hepatică (ADH). Principalii metaboliţi toxici sunt acidul glicolic, ce determină o acidoză importantă, şi acidul oxalic, care prin legare de calciu determină formarea de cristale de oxalat de calciu. Depunerea cristalelor în diverse organe explică afectarea multisistemică. Precipitarea oxalatului de calciu la nivel renal poate determina necroza epiteliului tubular, cu scăderea filtrării glomerulare şi apariția insuficienței renale (2).

\section{PREZENTAREA CAZULUI CLINIC}

Prezentăm cazul unui adolescent în vârstă de 16 ani transferat la Spitalul de Urgență pentru copii Sf.
Maria, Iaşi, dintr-o altă unitate medicală unde s-a prezentat cu cefalee, dureri abdominale şi vărsături. Simptomatologia a debutat cu 48 de ore anterior internării, după ingestia de aproximativ $1.500 \mathrm{ml}$ de vin şi bere. Examenul clinic inițial a relevat confuzie şi tulburări de echilibru. Biologic s-a remarcat: acidoză metabolică importantă (rezervă alcalină de $10 \mathrm{mEq} / \mathrm{l})$, cu hiatus anionic crescut $(22)$, retenție azotată (uree $=0,78 \mathrm{~g} / 1$, creatinină $=1,8 \mathrm{mg} / \mathrm{dl}$ ), oligurie cu hematurie microscopică şi test alcoolmetric respirator negativ. S-au administrat fluide intravenos şi bicarbonat de sodiu. După 6 ore, creşterea valorilor ureei şi creatininei şi oliguria severă au impus transferul către secția de Terapie Acută.

La sosirea în clinică, pacientul prezenta stare generală gravă, confuzie cu scurte perioade de halucinații, dureri abdominale, scaune diareice, oligurie $(0,17 \mathrm{ml} / \mathrm{kg} / \mathrm{h})$, urini hematurice. Biologic s-a evidențiat leucocitoză cu neutrofilie, sindrom de retenție azotată (uree $=56 \mathrm{mg} / \mathrm{dl}$, creatinină $=3,54$ $\mathrm{mg} / \mathrm{dl})$, acid uric crescut $(8,8 \mathrm{mg} / \mathrm{dl})$, ), $\mathrm{pH}=7,33$, rezervă alcalină $=18,8 \mathrm{mmol} / 1 \mathrm{cu}$ hiatus anionic 
aproape normal (18), discretă hiponatremie $(\mathrm{Na}=$ $133 \mathrm{mEq} / \mathrm{l})$. Hiatusul osmolar nu a putut fi calculat din cauza faptului că nu am putut determina osmolaritatea. Sumarul de urină a evidențiat hematurie, proteinurie, leucociturie, frecvente cristale de oxalat de calciu. Testul toxicologic urinar a fost negativ. În acel moment, s-a conturat diagnosticul de insuficiență renală acută, prin nefrită interstițială de cauză septică sau toxică şi s-a instituit tratament cu bicarbonat şi antibioterapie. Familia pacientului a negat ingestia de etilenglicol.

La o zi de la internare, pacientul era în continuare confuz, prezenta retenție azotată marcată (creatinină $=6,49 \mathrm{mg} / \mathrm{dl}$ ), clearence de creatinină 20,49 $\mathrm{ml} / \mathrm{min} / 1,73 \mathrm{~m}^{2}$, accentuarea oliguriei şi a hipertensiunii arteriale $(\mathrm{TA}=165 / 95 \mathrm{mmHg}$ ), ce au impus inițierea hemodializei. La 48 de ore de la internare, rezultatul testului toxicologic din ser confirmă intoxicaţia cu etilenglicol. La reluarea anamnezei în momentul în care pacientul a fost conştient şi cooperant, acesta a relatat că a cumpărat Antigel, pe care prietenii l-au turnat ulterior în vin.
Pacientul a efectuat 7 şedințe de hemodializă, asociate $\mathrm{cu}$ antibioterapie, antihipertensive, tratament suportiv, sub care evoluția a fost favorabilă, cu normalizarea funcției renale şi a tensiunii arteriale (Fig. 1). Pacientul a fost externat după 14 zile cu stare generală bună, hematurie şi proteinurie minină. La o lună după episodul acut, tabloul biologic a fost în limite normale.

\section{DISCUṬII}

Intoxicația cu etilenglicol la copil se produce, cel mai frecvent, prin ingestia de antigel. EG este rapid absorbit în tractul gastro-intestinal, având un peak plasmatic la 1-4 ore. Doza letală este de 1-1,4 $\mathrm{ml} / \mathrm{kg}$ de etilenglicol pur. Nivel seric de etilenglicol $>20 \mathrm{mg} / \mathrm{dl}$ a fost asociat cu mortalitate $98 \%$ în lipsa tratamentului (3).

Simptomatologia intoxicației cu etilenglicol evoluează clasic în trei stadii. Iniţial, în primele 12 ore de la ingestie, pacienții prezintă confuzie, halucinații, euforie, convulsii, deprimarea sistemului
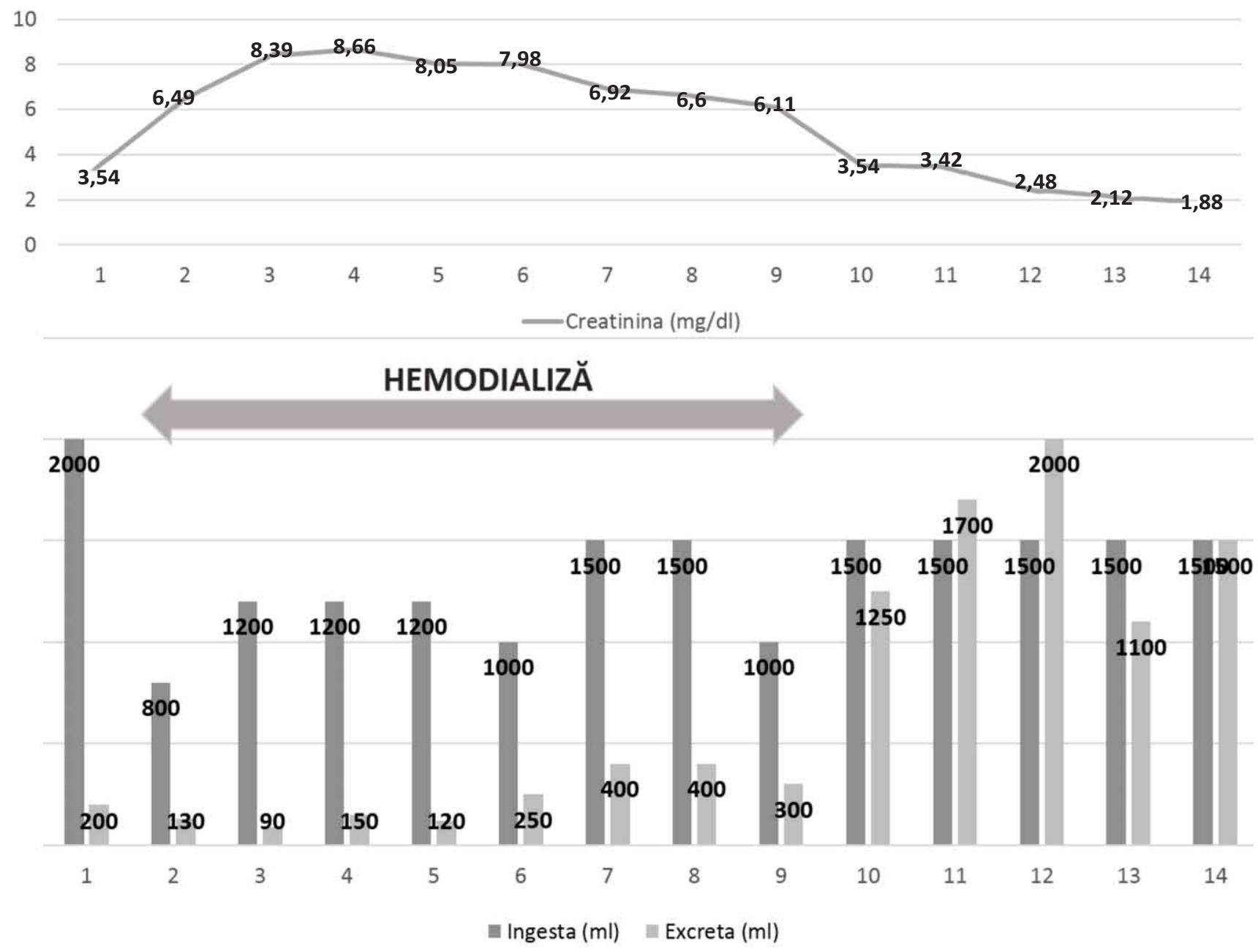

FIGURA 1. Modificările ingestei, excretei şi valorilor creatininei în dinamică 
nervos central şi semne generale de intoxicație, ca: greață, vărsături, diaree. În aproximativ 12-24 de ore de la ingestie se asociază semne cardiovasculare şi respiratorii, cu dispnee, tahicardie, cianoză, hipertensiune arterială, aritmii, ca urmare a acumulării de acizi organici prin metabolizarea etilenglicolului. Stadiul final, ce apare după 24-48 de ore, este caracterizat prin oligurie, necroză tubulară, hematurie, proteinurie, insuficiență renală acută (4). Cazurile severe de intoxicație pot prezenta tardiv (1-2 săptămâni) afectare neurologică, cu neuropatia nervilor cranieni, paralizii faciale, pierderea achizițiilor motorii, afectare vizuală. Pe termen lung nu au fost observate însă afectări renale sau neurologice cu debut întârziat (5).

Diagnosticul poate fi uneori dificil în absența unei anamneze pozitive. Multe dintre semnele şi simptomele intoxicației cu etilenglicol sunt nespecifice şi sunt comune altor intoxicații. Diagnosticul de certitudine este dat de rezultatul testelor toxicologice. Măsurarea concentraţiei de etilenglicol în sânge, prin metoda cromatografică, este laborioasă şi de cele mai multe ori inaccesibilă în multe spitale (6). Prezența unei acidoze severe şi a unui hiatus osmolar şi/sau anionic crescut poate orienta diagnosticul spre o intoxicație cu etilenglicol (7). Examenul de urină poate pune în evidență prezența de oxalați de calciu, cu toate că aceste cristale pot să nu apară decât în stadiile tardive (2). Intoxicaţia severă şi decesul au fost semnalate în studii clinice în absenţa cristalelor de oxalat de calciu şi a hiatusului anionic. Alte anomalii metabolice ce pot fi întâlnite sunt hipocalcemia şi hiperkaliemia.

Tratamentul intoxicației cu etilenglicol include terapie suportivă (corectarea dezechilibrului acidobazic, administrarea de fluide intravenos, susținere ventilatorie), utilizarea de antidoturi şi hemodializă (8). Din cauza absorbției rapide în tractul digestiv, decontaminarea gastrică are eficacitate limitată. Bicarbonatul de sodiu este recomandat pentru corectarea acidozei metabolice. Antidotul în intoxicația cu etilenglicol este reprezentat de inhibitori ai alcooldehidrogenazei: etanol sau fomepizole. Etanolul este un substrat competitiv pentru alcooldehidrogenază, iar fomepizolul este un inhibitor al enzimei (9). Administrarea precoce a antidotului poate preveni apariția insuficienței renale şi este mai eficient înaintea formării unui nivel semnificativ de metaboliți toxici. Hemodializa este considerată un element cheie în intoxicația severă cu etilenglicol. Hemodializa elimină etilenglicolul şi metaboliții săi toxici, corectează hiatusul anionic, reduce perioada de administrare a antidotului şi durata spitalizării (8).

Tratamentul intoxicației cu etilenglicol trebuie inițiat la simpla suspiciune pentru evitarea complicațiilor severe. Prognosticul renal pe termen lung este corelat cu afectarea tubulointerstițială determinată de nefrocalcinoză (2), în unele cazuri fiind necesară dializă cronică sau transplant renal.

În cazul nostru, absența acidozei metabolice persistente şi a hiatusului anionic a întârziat diagnosticul până la confirmarea prin testul toxicologic. Ingerarea concomitentă de etanol a crescut timpul de înjumătătire al EG, ca urmare a rolului său ca substrat competitiv pentru $\mathrm{ADH}$, a cărui afinitate pentru etanol este mai mare decât pentru EG; astfel, metabolismul EG şi acumularea de acizi organici toxici au fost întârziate, explicând lipsa acidozei metabolice.

Cazuri similare au fost descrise de literatura de specialitate, cauzate de ingestia concomitentă de EG şi etanol (10,11), EG şi metanol (12), sugerând că lipsa acidozei metabolice şi a hiatusului anionic nu exclud diagnosticul de intoxicație cu EG.

Deoarece pacientul a fost confuz şi nu am avut o anamneză pozitivă, administrarea orală a antidotului a fost amânată; mai mult, în spitalul nostru nu era disponibil nici un antidot cu administrare intravenoasă (etanol sau fomepizol) la acel moment. În ciuda deteriorării rapide, evoluția a fost însă favorabilă, datorită hemodializei, care a îmbunătățit funcția renală şi a corectat dezechilibrele metabolice.

\section{CONCLUZII}

Absența acidozei metabolice persistente nu exclude diagnosticul de intoxicație cu EG. Aportul concomitent de alcool ar putea acționa ca o capcană de diagnostic. Un pacient anterior sănătos, internat cu disfuncție neurologică şi renală acută, ar trebui să fie investigat pentru o intoxicație cu EG, chiar dacă nu există nici un istoric de ingestie şi nici acidoză metabolică. Hemodializa este extrem de eficientă în tratamentul intoxicației severe cu etilenglicol. 